\section{Mass distribution descriptors in modelling of sorption properties}

${ }^{1}$ Tulegenov A.S.*, ${ }^{2}$ Kenzhaliyev B.K., ${ }^{1}$ Seilkhanova Zh.K., ${ }^{1}$ Sartayeva M.M

${ }^{1}$ Al-Farabi Kazakh National University, Almaty, Kazakhstan

${ }^{2}$ Kazakh-British Technical University, Almaty, Kazakhstan

*E-mail: akyl.s.tulegenov@gmail.com
The objective of present work is to construct structure-property models for the prediction of applied thermochemical properties of polyatomic molecules based on the mass distribution descriptors. The performance of the model was assessed based on the values of coefficients of determination and root mean square deviations. The results were compared with existing literature values, and it was observed that the mass distribution descriptors not relying on quantum-chemical information exhibit a similar performance compared to quantum-chemical QSPR models and can at least form the reliable foundation for the construction of the quantitative structure-property models. Conclusions were made about the possible applicability of the model.

Keywords: mass distribution descriptor; node; QSPR; modelling; sorption; correlation; rms.
Дескрипторы

распределения массы в моделировании сорбционных свойств

${ }^{1}$ Тулегенов А.С.*, ${ }^{2}$ Кенжалиев Б.К., ${ }^{1}$ Сейлханова Ж.К., ${ }^{1}$ Сартаева М.М.

${ }^{1}$ Казахский национальный университет им. аль-Фараби, Алматы, Казахстан Казахско-Британский технический университет, Алматы, Казахстан *E-mail: akyl.s.tulegenov@gmail.com
Целью данной работы ставилось построение моделей структура - свойство для предсказания термохимических свойств многоатомных молекул на основе дескрипторов распределения массы. В работе были оценены характеристики методов на основе значений коэффициентов корреляции и среднеквадратического отклонения и был проведен сравнительный анализ результатов с существующими литературными данными, который показал, что дескрипторы распределения массы, не зависящие от квантово-химических параметров, проявляют высокий уровень точности и могут быть использованы в качестве фундамента для построения более сложных квантово-химических моделей «структура-свойство». Сделаны выводы о возможной применимости модели.

Ключевые слова: дескриптор массового распределения; узел; QSPR; моделирование; сорбция; корреляция; среднеквадратичное значение.

\section{Масса үлестірім дескрипторлар модель арқылы сорбция қасиеттерін болжау}

${ }^{1}$ Тулегенов А.С.*, ${ }^{2}$ Кенжалиев Б.К., ${ }^{1}$ Сейлханова Ж.К., ${ }^{1}$ Сартаева М.М.

1Әл-Фараби атындағы Казақ ұлттық университеті, Алматы, Қазақстан ${ }^{2}$ Қазақстан-Британ техникалық университеті, Алматы, Қазақстан *E-mail: akyl.s.tulegenov@gmail.com
Берілген жұмыста көпатомды молекулалардын термохимиялық қасиеттерін болжауына арналған масса үлестірім модель арқылы құрылым-қасиет модельдерін құрастыру мақсаты қойылған. Жұмыста корреляция коэффициенттер және орташа квадрат ауысу арқыль әдістерінің сипаттамалар бағытталған. Нәтижелер әдебиет мәліметіменен салыстырылған. Жұмыста кванттык химиялық қасиеттеріне тәуелсіз масса үлестірім моделінің жоғары болжау қабілеттілігі көрсетілген және күрделі "құрылым-қасиет" модельдерінің негізі ретінде қолданбалы қабілеттілігі көрсетілген. Модельдін қолданбалы мүмкіншілігі тұралы орытындылар жасалынған.

Түйін сөздер: жаппай тарату дескрипторы; түйін; QSPR; модельдеу; сорбция; корреляция; rms мәні. 


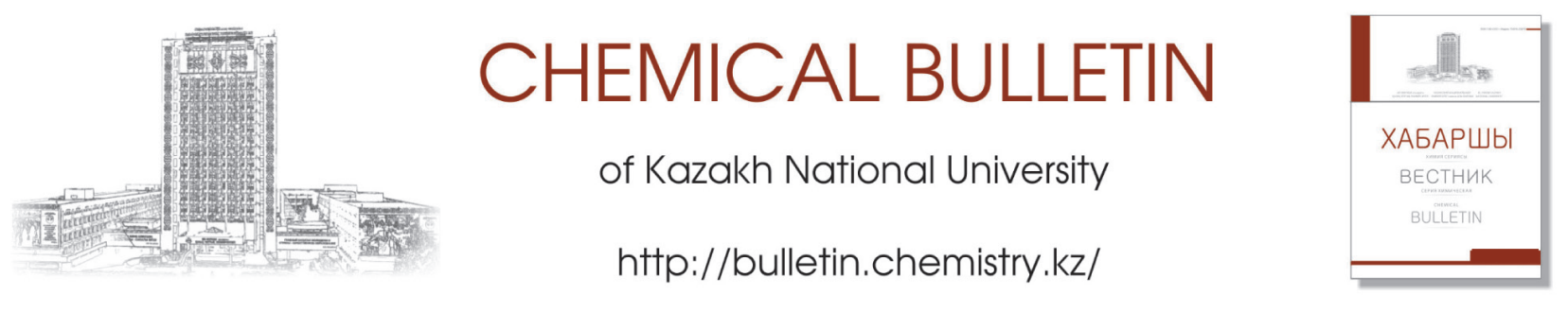

http://doi.org/10.15328/cb968

\title{
Mass distribution descriptors in modelling of sorption properties
}

\author{
${ }^{1}$ Tulegenov A.S. ${ }^{*},{ }^{2}$ Kenzhaliyev B.K., ${ }^{1}$ Seilkhanova Zh.K., ${ }^{1}$ Sartayeva M.M. \\ ${ }^{1}$ Al-Farabi Kazakh National University, Almaty, Kazakhstan \\ ${ }^{2}$ Kazakh-British Technical University, Almaty, Kazakhstan \\ *E-mail: akyl.s.tulegenov@gmail.com
}

\section{Introduction}

The quantitative structure-property relationship (QSPR) models find wide applications in modern chemistry $[1,2]$. Their ability to model the properties of substances makes them a good alternative to certain types of experiments and ab initio studies due to time efficiency and computational affordability.

The effort was made in present work to construct and apply the system of descriptors that would model the sorption properties of compounds from various classes. On the path of attaining this objective, the system of descriptors was constructed based on proton mass distribution [3]. To explore the limits of applicability of the model, several comparative studies were carried out in present study. The comparisons were made with the literature data of the results of two previous works $[4,5]$. The first work was devoted to modelling of aqueous biphasic systems (ABS) using QSPR methodogy based on quantumchemical descriptors relying on the information about dipole moments, interatomic distances, atomic charges [4]. The second work was devoted to the study of the retention volume of organic molecules adsorbed on Carbotrap graphitized carbon material [5]. The set of physical-chemical properties was utilized in the construction of model of retention volume. The similarity of both systems used in these studies is in the molecular mechanism of the process, which is the intermolecular interaction responsible for sorption process. And it was this type of property that the technique used in present work was applied to. The common characteristic of the majority of QSPR methodologies is in the utilization of ab initio descriptors originating from quantum-chemical computations [2,4]. Such computations are often time-consuming and become nontrivial for polyatomic molecules. In this research, we explored the possibilities of description of physical-chemical properties without the use of quantum-chemical computations, i.e., utilizing the basic knowledge about the substance to construct the models of macroscopic thermochemical properties. The choice of descriptors was suggested by the effort to model the molecular charge distribution utilizing only the concepts of distribution of mass. The first option was to utilize the concept of multipolar moments, but it involves the necessity to solve the problem of divergence of multipolar series. To find the nonexpanded property, we utilized the concept of distribution of mass, which is close in physical meaning to the gravitational index [5], but we were searching to find the property that would not rely on quantum-chemical computation or any molecular structural data.The choice of descriptors utilized in the present work [4] is close in similitude to the concept of molecular mass distribution in polymer science [1], but is based on the analogies from the theory of intermolecular forces and when extended to the description of polymers would correspond to the case when polymer is formed as a heterogeneous chain with monomer units possessing the alternating structure.

\section{Methods}

The multilinear regression methodology was utilized in all methods used in present work. The least squares deviation of model values from experimental values was minimized (formula)

$$
\Delta=\sum\left(Q-Q_{\text {comp }}\right)^{2}=\min
$$

The form of Qcomp depended upon the nature of the model used. In the previously described atomic mass distribution descriptors method [4], there is utilized only the chemical formula of the substance, which is used to construct the atomic (protonic) mass distribution functions.The degree of mass in summation was varied from 1 to 3 , which corresponds to various models with various dimensionalities. The given descriptors are the measure of the degree of spatial interatomic distribution of charge in the molecule. For illustrative purposes, it is instructive 
to reason based on the deviation from the presumably spherical shape of the molecule with deviation corresponding to the presence of polarity. The higher the polarity, the higher is the degree of intermolecular interaction. The mass distribution descriptor (linear, quadratic, cubic) characterizes the degree of interatomic distribution of the mass of protons (or the degree of their localization on an atom) in molecule. The higher this number, the less distributed is the mass, i.e. the molecule is more compact, in other words - the molecule possesses the lower polarity. Furthermore, one may anticipate that the lower is this number the higher is the number of atoms in molecule, which indirectly characterizes the polarizability, as the increase of the number of atoms leads to the increase of the volume of the molecule, and dimensionality unit of polarizability is equal to the dimensionality unit of volume. As an example, the isoelectronic series is considered composed of $\mathrm{Ne}, \mathrm{HF}, \mathrm{H}_{2} \mathrm{O}, \mathrm{NH}_{3^{\prime}}$ $\mathrm{CH}_{4}$ with the total number of electrons being equal to 10 . The quadratic and cubic terms of the model introduce additional degree of variational freedom of the model to account for the nonlinearity of the relationship between the interatomic proton mass distribution and electronic properties of the molecule.

The typical values of the descriptors for the isoelectronic molecules are shown in Table 1. Distribution of numbers in the results of computation characterizes $\mathrm{Ne}\{10,10 \cdot 10,10 \cdot 10 \cdot 10\}-$ as a sphere and chemically inert, $\operatorname{HF}\{(1+9) / 2,(1+9 \cdot 9) / 2$, $(1+9.9 \cdot 9) / 2\}$ - linear molecule possessing high dipole moment and producing high polarizing effect, $\mathrm{NH}_{3}\{(7+3) / 4,(7 \cdot 7+3) / 4$, $(7 \cdot 7 \cdot 7+3) / 4\}$ - the molecule possessing dipole moment and exhibiting electronic donor properties, $\mathrm{CH}_{4}\{(6+4) / 5,(6 \cdot 6+4) / 5$, $(6 \cdot 6 \cdot 6+4) / 5\}$ - molecule possessing no dipole moment but high polarizability responsible for hydrophobicity of alkanes. Correspondingly, $\mathrm{Ne}$ and $\mathrm{CH}_{4}$ form weak intermolecular bonds, $\mathrm{HF}$ and $\mathrm{NH}_{3}$ - form polar intermolecular complexes due to their polarity. The advantage of this scheme is that no geometric information is utilized, and the description is limited to chemical formula. The quantity modelled (distribution coefficient or retention volume utilized in present work) is expressed as

$$
\begin{gathered}
Q_{\text {comp }}=\sum_{i} e_{i} \times v_{i} \\
\bar{v}=\left\{\sum_{k} m_{k}, \sum_{k} m_{k}^{2}, \sum_{k} m_{k}^{3}, \sum_{k} m_{k}^{4}, n, 1\right\} \\
\frac{\partial \Delta}{\partial e_{i}}=0
\end{gathered}
$$

The expanded form of the model is

$Q_{\text {comp }}=e_{1} v_{1}+e_{2} v_{2}+e_{3} v_{3}+e_{4} v_{4}+e_{5} v_{5}+e_{6} v_{6}$

Conditions expressed in equation (4) lead to the system of linear algebraic equations (6) allowing to find the parameters of the model

$$
\begin{aligned}
& e_{1} \sum v_{i, 1} v_{i, 1}+e_{2} \sum v_{i, 1} v_{i, 2}+e_{3} \sum v_{i, 1} v_{i, 3}+e_{4} \sum v_{i, 1} v_{i, 4}+e_{5} \sum v_{i, 1} v_{i, 5}+e_{6} \sum v_{i, 1} v_{i, 6}=\sum Q_{i} v_{i, 1} \\
& e_{1} \sum v_{i, 2} v_{i, 1}+e_{2} \sum v_{i, 2} v_{i, 2}+e_{3} \sum v_{i, 2} v_{i, 3}+e_{4} \sum v_{i, 2} v_{i, 4}+e_{5} \sum v_{i, 2} v_{i, 5}+e_{6} \sum v_{i, 2} v_{i, 6}=\sum Q_{i} v_{i, 2} \\
& e_{1} \sum v_{i, 3} v_{i, 1}+e_{2} \sum v_{i, 3} v_{i, 2}+e_{3} \sum v_{i, 3} v_{i, 3}+e_{4} \sum v_{i, 3} v_{i, 4}+e_{5} \sum v_{i, 3} v_{i, 5}+e_{6} \sum v_{i, 3} v_{i, 6}=\sum Q_{i} v_{i, 3} \\
& e_{1} \sum v_{i, 4} v_{i, 1}+e_{2} \sum v_{i, 4} v_{i, 2}+e_{3} \sum v_{i, 4} v_{i, 3}+e_{4} \sum v_{i, 4} v_{i, 4}+e_{5} \sum v_{i, 4} v_{i, 5}+e_{6} \sum v_{i, 4} v_{i, 6}=\sum Q_{i} v_{i, 4} \\
& e_{1} \sum v_{i, 5} v_{i, 1}+e_{2} \sum v_{i, 5} v_{i, 2}+e_{3} \sum v_{i, 5} v_{i, 3}+e_{4} \sum v_{i, 5} v_{i, 4}+e_{5} \sum v_{i, 5} v_{i, 5}+e_{6} \sum v_{i, 5} v_{i, 6}=\sum Q_{i} v_{i, 5} \\
& e_{1} \sum v_{i, 6} v_{i, 1}+e_{2} \sum v_{i, 6} v_{i, 2}+e_{3} \sum v_{i, 6} v_{i, 3}+e_{4} \sum v_{i, 6} v_{i, 4}+e_{5} \sum v_{i, 6} v_{i, 5}+e_{6} \sum v_{i, 6} v_{i, 6}=\sum Q_{i} v_{i, 6}
\end{aligned}
$$

Table1 - Isoelectronic series example

\begin{tabular}{lllll}
\hline Molecule & $\begin{array}{l}\text { Number of } \\
\text { atoms }\end{array}$ & $\begin{array}{l}\text { Average } \\
\text { sum of } \\
\text { protons }\end{array}$ & $\begin{array}{l}\text { Average } \\
\text { quadratic } \\
\text { sum }\end{array}$ & $\begin{array}{l}\text { Average cubic } \\
\text { sum }\end{array}$ \\
\hline $\mathrm{Ne}$ & 1 & 10.0 & 100.0 & 1000.0 \\
$\mathrm{HF}$ & 2 & 5.0 & 41.0 & 365.0 \\
$\mathrm{H}_{2} \mathrm{O}$ & 3 & 3.3 & 22.0 & 171.3 \\
$\mathrm{NH}_{3}$ & 4 & 2.5 & 13.0 & 86.5 \\
$\mathrm{CH}_{4}$ & 5 & 2.0 & 8.0 & 44.0 \\
\hline
\end{tabular}

The method can systematically be extended to account for the cases of possible incompleteness in the description of structure of isomers. In order to accomplish this task, the concept of pseudoatom or the node can be introduced describing the regions of bonds formation. For instance, in $\mathrm{CH}_{4}$, there is only one branching node, in $\mathrm{C}_{2} \mathrm{H}_{6}$-two. It is possible then to introduce the measure of mass distribution of the nodes and count the nodes in the molecule in addition to counting the atoms. For example, we consider the case of n-propanol and 2-propanol. The difference between these two molecules is that the nature of branching is different. In n-propanol, the nodes are $\mathrm{C}\left(\mathrm{H}_{3} \mathrm{C}\right)$, 
$\mathrm{C}\left(\mathrm{H}_{2} \mathrm{C}_{2}\right), \mathrm{C}\left(\mathrm{H}_{2} \mathrm{CO}\right), \mathrm{O}(\mathrm{CH})$ leading to $15,20,22,15$, respectively. In 2-propanol, the nodes are $\mathrm{C}\left(\mathrm{H}_{3} \mathrm{C}\right), \mathrm{C}\left(\mathrm{C}_{2} \mathrm{HO}\right), \mathrm{O}(\mathrm{CH}), \mathrm{C}\left(\mathrm{CH}_{3}\right)$ leading to $15,27,15,15$, respectively. There are then possible several levels of mass distribution hierarchy - atom, node, branch, etc. with the atom characterizing the elemental composition, node and branch - structural chemical composition. The parameters scheme for the nodes-based complemented mass distribution descriptors model is provided in the equation 7. The existing atomic mass distribution descriptors are complemented by nodes-based mass distribution descriptors.

The evaluation of validity of models was made based on computation of coefficients of determination and root mean square deviations using equations 8 and 9 .

$$
\begin{gathered}
\bar{v}=\left\{\sum_{k} m_{k}, \sum_{k} m_{k}^{2}, \sum_{k} m_{k}^{3}, \sum_{k} m_{k}^{4}, n, \sum_{k} m_{\text {node }, k}, \sum_{k} m_{\text {node }, k}^{2}, \sum_{k} m_{\text {node }, k}^{3} \cdot n_{\text {node }}, 1\right\} \\
R^{2}=\frac{\sum_{i}^{\left(Q_{\text {comp }, i}-\bar{Q}\right)\left(Q_{\text {comp }, i}-Q\right)}}{\sum_{i}\left(Q_{\text {exp }, i}-\bar{Q}\right)\left(Q_{\text {exp }, i}-\bar{Q}\right)} \quad \text { (8) } \quad R M S=\frac{\sqrt{\sum_{i}\left(Q_{\text {comp }, i}-\bar{Q}\right)\left(Q_{\text {comp }, i}-\bar{Q}\right)}}{\sqrt{N}}
\end{gathered}
$$

\section{Results and Discussion}

To evaluate the range of applicability and substantiate the assumption about preferential applicability to modelling sorption processes, the system of mass distribution descriptors was tested on two sets of results modelling the distribution coefficients of organic molecules belonging to different classes of substances and retention volumes of organic molecules. The data of [5] was used, and results were compared with the results obtained by models obtained in [5]. To explore the possible extension of the mass distribution model to make improvements of performance, several additional descriptors were applied including chemical hardness (proportional to the difference between LUMO and HOMO energies) and electronegativity (proportional to the sum of LUMO and HOMO energies). The final result remained invariant to the supplement by quantumchemical descriptors making almost negligible alterations to the coefficients of determination and RMS deviations of the results

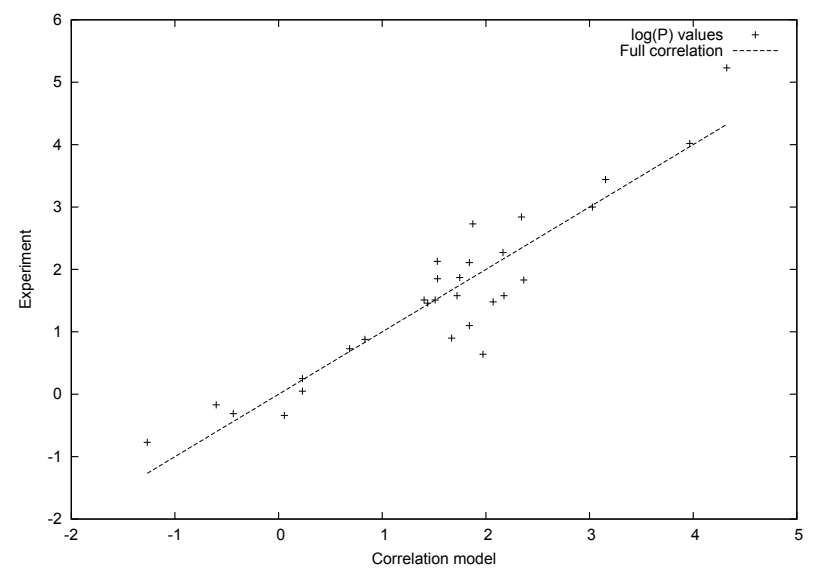

Figure 1 - Results of modelling of $\log P$ values using atom-based mass distribution descriptors provided by models based only on mass distribution descriptors. The results of evaluation of performance of the models are shown in Tables 2-5 and Figures 1-2.

Coefficients of determination for the models of $\log D$ (PEG) and $\log P$ (octanol) obtained using mass distribution descriptors are equal to 0.91 and 0.86 correspondingly. Comparatively large deviation of the results for benzamide in case of modelling of $\log P$ values may be attributed to the complex nature of interaction pattern of this molecule with the solvent due to the presence of heteropolar amide group consisting of $\mathrm{NH}$ and $\mathrm{CO}$ dipolar groups along with the dependence upon the conformational state, which would necessitate the introduction of additional descriptors. A distinctive difference between the octanol and PEG data modelling is in the fact that ABS containing $P E G$ is composed of polymer with interacting fragments fixed in space, such that making the interaction more directed and the whole framework of the polymer closer in similitude to the surface rather then the liquid. Such arrangement of interacting

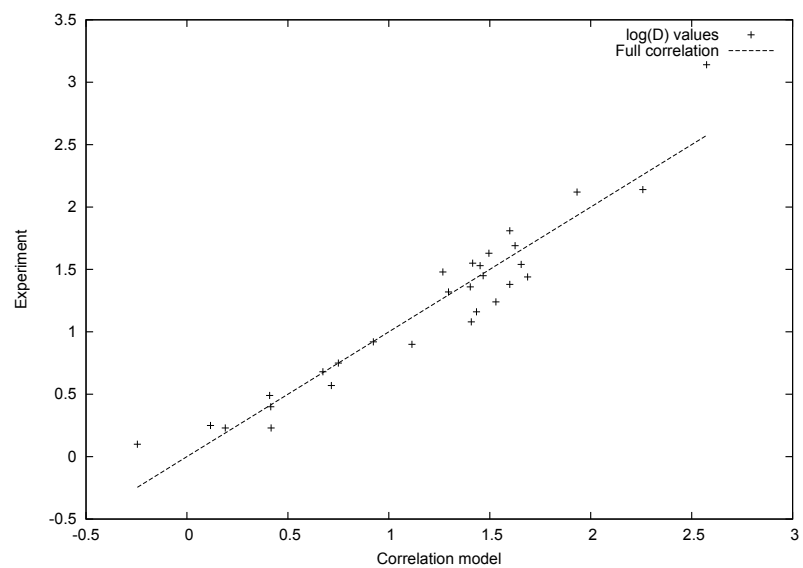

Figure 2 - Results of modelling $\log D$ values using atom-based mass distribution descriptors 
units makes the importance of local (depending on specific orientation and interatomic orientation) interactions less pronounced. In the case of octanol, all kinds of orientations contribute to the total interaction energy due to constant translational and rotational motion of molecules, hence, making the locality and anisotropy of interaction more important and creating stricter conditions for the degree of accuracy of the model of charge distribution. In order to check this assumption, additional tests were carried out by modelling the retention volume of organic compounds on Carbotrap graphitized carbon material [6]. The best representative result of modelling is shown in Figure 3. The coefficient of determination of the mass distribution model for this type of interaction is 0.98 , which supports the assumption of lower importance of the locality of interaction in modelling sorption properties.

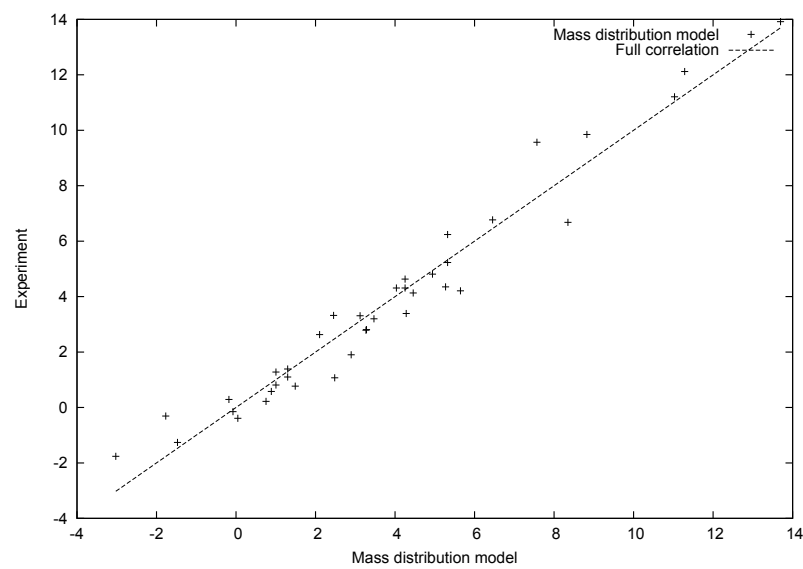

Figure 3 - Retention volume on Carbotrap graphitized carbon material $\left(R^{2}=0.98\right)$

Table $2-\log D$ values modelled using mass distribution descriptors

\begin{tabular}{|c|c|c|c|c|c|c|c|c|}
\hline Substance & C & $\mathrm{H}$ & 0 & $\mathrm{~N}$ & $\mathrm{Cl}$ & Atoms-based & Nodes-based & Exp. [5] \\
\hline Benzene & 6 & 6 & 0 & 0 & 0 & 1.28 & 1.24 & 1.48 \\
\hline Toluene & 7 & 8 & 0 & 0 & 0 & 1.39 & 1.33 & 1.55 \\
\hline 1,2-Dichloroethane & 2 & 4 & 0 & 0 & 2 & 1.07 & 0.80 & 0.90 \\
\hline Ethylacetate & 4 & 8 & 2 & 0 & 0 & 0.74 & 0.73 & 0.57 \\
\hline Methanol & 1 & 4 & 1 & 0 & 0 & -0.30 & -0.004 & 0.10 \\
\hline Ethanol & 2 & 6 & 1 & 0 & 0 & 0.1 & 0.16 & 0.25 \\
\hline$n$-Propanol & 3 & 8 & 1 & 0 & 0 & 0.42 & 0.45 & 0.49 \\
\hline 2-Propanol & 3 & 8 & 1 & 0 & 0 & 0.42 & 0.49 & 0.40 \\
\hline$n$-Butanol & 4 & 10 & 1 & 0 & 0 & 0.70 & 0.70 & 0.68 \\
\hline$n$-Pentanol & 5 & 12 & 1 & 0 & 0 & 0.96 & 0.93 & 0.92 \\
\hline$n$-Octanol & 8 & 18 & 1 & 0 & 0 & 1.72 & 1.56 & 1.54 \\
\hline Chlorobenzene & 6 & 5 & 0 & 0 & 1 & 1.62 & 1.86 & 1.81 \\
\hline Acetonitrile & 2 & 3 & 0 & 1 & 0 & 0.58 & 0.24 & 0.23 \\
\hline Aniline & 6 & 7 & 0 & 1 & 0 & 1.33 & 1.29 & 1.08 \\
\hline Acetophenone & 8 & 8 & 1 & 0 & 0 & 1.59 & 1.44 & 1.38 \\
\hline 4-Hydroxybenzoic acid & 7 & 6 & 3 & 0 & 0 & 1.47 & 1.46 & 1.63 \\
\hline Benzyl alcohol & 7 & 8 & 1 & 0 & 0 & 1.39 & 1.39 & 1.16 \\
\hline Acetic acid & 2 & 4 & 2 & 0 & 0 & 0.21 & 0.26 & 0.23 \\
\hline Benzoic acid & 7 & 6 & 2 & 0 & 0 & 1.47 & 1.42 & 1.45 \\
\hline Nitrobenzene & 6 & 5 & 2 & 1 & 0 & 1.42 & 1.32 & 1.36 \\
\hline Methyl iodide & 1 & 3 & 0 & 0 & 0 & 0.75 & 0.75 & 0.75 \\
\hline Anisole & 7 & 8 & 1 & 0 & 0 & 1.40 & 1.48 & 1.53 \\
\hline Phenol & 6 & 6 & 1 & 0 & 0 & 1.26 & 1.25 & 1.32 \\
\hline 1,4-Dichlorobenzene & 6 & 4 & 0 & 0 & 2 & 1.96 & 2.11 & 2.12 \\
\hline 1,2,4-Trichlorobenzene & 6 & 3 & 0 & 0 & 3 & 2.29 & 2.21 & 2.14 \\
\hline 4,4-Dichlorobiphenyl & 12 & 8 & 0 & 0 & 2 & 2.59 & 2.88 & 3.14 \\
\hline$p$-Toluic acid & 8 & 8 & 2 & 0 & 0 & 1.61 & 1.55 & 1.69 \\
\hline Benzamide & 7 & 7 & 1 & 1 & 0 & 1.54 & 1.43 & 1.24 \\
\hline 4-Chloroaniline & 6 & 6 & 0 & 1 & 1 & 1.62 & 1.84 & 1.44 \\
\hline
\end{tabular}


Table 3 - Log $P$ values modelled using mass distribution descriptors model

\begin{tabular}{|c|c|c|c|c|c|c|c|c|}
\hline Substance & C & $\mathrm{H}$ & 0 & $\mathrm{~N}$ & $\mathrm{Cl}$ & Atoms-based & Nodes-based & Exp. [5] \\
\hline Benzene & 6 & 6 & 0 & 0 & 0 & 1.53 & 1.51 & 2.13 \\
\hline Toluene & 7 & 8 & 0 & 0 & 0 & 1.87 & 1.66 & 2.73 \\
\hline 1,2-Dichloroethane & 2 & 4 & 0 & 0 & 2 & 2.07 & 1.44 & 1.48 \\
\hline Ethylacetate & 4 & 8 & 2 & 0 & 0 & 0.69 & 0.73 & 0.73 \\
\hline Methanol & 1 & 4 & 1 & 0 & 0 & -1.27 & -0.70 & -0.77 \\
\hline Ethanol & 2 & 6 & 1 & 0 & 0 & -0.44 & -0.44 & -0.31 \\
\hline$n$-Propanol & 3 & 8 & 1 & 0 & 0 & 0.23 & 0.27 & 0.25 \\
\hline 2-Propanol & 3 & 8 & 1 & 0 & 0 & 0.23 & 0.11 & 0.05 \\
\hline$n$-Butanol & 4 & 10 & 1 & 0 & 0 & 0.83 & 0.89 & 0.88 \\
\hline$n$-Pentanol & 5 & 12 & 1 & 0 & 0 & 1.40 & 1.47 & 1.51 \\
\hline n-Octanol & 8 & 18 & 1 & 0 & 0 & 3.03 & 3.10 & 3.00 \\
\hline Chlorobenzene & 6 & 5 & 0 & 0 & 1 & 2.34 & 3.061 & 2.84 \\
\hline Acetonitrile & 2 & 3 & 0 & 1 & 0 & 0.06 & -0.15 & -0.34 \\
\hline Aniline & 6 & 7 & 0 & 1 & 0 & 1.67 & 1.48 & 0.90 \\
\hline Acetophenone & 8 & 8 & 1 & 0 & 0 & 2.17 & 1.87 & 1.58 \\
\hline 4-Hydroxybenzoic acid & 7 & 6 & 3 & 0 & 0 & 1.72 & 1.53 & 1.58 \\
\hline Benzylalcohol & 7 & 8 & 1 & 0 & 0 & 1.84 & 1.69 & 1.10 \\
\hline Acetic acid & 2 & 4 & 2 & 0 & 0 & -0.60 & -0.45 & -0.17 \\
\hline Benzoic acid & 7 & 6 & 2 & 0 & 0 & 1.75 & 1.62 & 1.87 \\
\hline Nitrobenzene & 6 & 5 & 2 & 1 & 0 & 1.53 & 1.60 & 1.85 \\
\hline Methyl iodide & 1 & 3 & 0 & 0 & 0 & 1.51 & 1.51 & 1.51 \\
\hline Anisole & 7 & 8 & 1 & 0 & 0 & 1.84 & 1.87 & 2.11 \\
\hline Phenol & 6 & 6 & 1 & 0 & 0 & 1.43 & 1.30 & 1.46 \\
\hline 1,4-Dichlorobenzene & 6 & 4 & 0 & 0 & 2 & 3.15 & 3.49 & 3.44 \\
\hline 1,2,4-Trichlorobenzene & 6 & 3 & 0 & 0 & 3 & 3.97 & 3.88 & 4.02 \\
\hline 4,4-Dichlorobiphenyl & 12 & 8 & 0 & 0 & 2 & 4.32 & 4.81 & 5.23 \\
\hline$p$-Toluic acid & 8 & 8 & 2 & 0 & 0 & 2.17 & 1.90 & 2.27 \\
\hline Benzamide & 7 & 7 & 1 & 1 & 0 & 1.97 & 1.73 & 0.64 \\
\hline 4-Chloroaniline & 6 & 6 & 0 & 1 & 1 & 2.36 & 2.62 & 1.83 \\
\hline
\end{tabular}

Table 4 - Parameters of the model of atom-based mass distribution descriptors

\begin{tabular}{ccccccc}
\hline & $\mathrm{e}_{1}$ & $\mathrm{e}_{2}$ & $\mathrm{e}_{3}$ & $\mathrm{e}_{4}$ & $\mathrm{e}_{5}$ & $\mathrm{e}_{6}$ \\
\hline $\log D$ & 9.8904 & -1.8348 & 0.09912 & -0.001281 & 0.168521 & -11.08808 \\
$\log P$ & 5.6433 & -0.9986 & 0.05237 & -0.000669 & 0.077283 & -6.174813 \\
\hline
\end{tabular}

Table 5 - Characteristics of the method of atom-based mass-distribution descriptors. For data from [5] (square root of $\mathrm{s}^{2}$ )

\begin{tabular}{ccccc}
\hline & \multicolumn{2}{c}{$\log D$} & $\log P$ \\
\hline & Atoms & {$[5]$} & Atoms & {$[5]$} \\
\hline $\mathrm{R}^{2}$ & 0.91 & 0.94 & 0.86 & 0.88 \\
$\mathrm{RMS}$ & 0.20 & $0.17\left(\right.$ square root of $\left.\mathrm{s}^{2}\right)$ & 0.49 & 0.49 (square root of $\left.\mathrm{s}^{2}\right)$ \\
\hline
\end{tabular}


In order to explore the effects of the information about the existence and distribution of intramolecular valence bound interatomic states produced upon the accuracy of modelling, the nodes-based complemented mass distribution model is applied in present work to the construction of the model of distribution coefficients of substances using the data from [5]. The results are provided in Tables 2, 3, 7 and 8. The introduc- tion of the nodes-based mass distribution descriptors improves the predictive power of the model and resolves the problem of the incompleteness in the description of the structure leading to the unique definition of the molecular formula within the mass distribution descriptors model and allows the observation the difference between the isomers at the level of descriptors.

Table 7 - Performance characteristics of the method of nodes-based mass distribution descriptors.

\begin{tabular}{|c|c|c|c|c|}
\hline & \multicolumn{2}{|r|}{$\log D$} & \multicolumn{2}{|c|}{$\log P$} \\
\hline & This work & [5] & This work & {$[5]$} \\
\hline $\mathrm{R}^{2}$ & 0.96 & 0.94 & 0.91 & 0.88 \\
\hline RMS & 0.14 & 0.17 (square root of $\mathrm{s}^{2}$ ) & 0.41 & 0.49 (square root of $\mathrm{s}^{2}$ ) \\
\hline
\end{tabular}

Table 8 - Parameters of the model of nodes-based complemented mass distribution descriptors

\begin{tabular}{|c|c|c|c|c|c|}
\hline & $\log D$ & $\log P$ & & $\log D$ & $\log P$ \\
\hline $\mathrm{e}_{1}$ & 2.311871 & 4.532165 & $\mathrm{e}_{6}$ & 4.356853 & 10.422386 \\
\hline $\mathrm{e}_{2}$ & -0.465578 & -0.899983 & $e_{7}$ & -0.213608 & -0.500303 \\
\hline $\mathrm{e}_{3}$ & 0.028244 & 0.057987 & $\mathrm{e}_{8}$ & 0.003426 & 0.007795 \\
\hline $\mathrm{e}_{4}$ & -0.000608 & -0.001294 & $e_{9}$ & 0.165462 & 0.033625 \\
\hline $\mathrm{e}_{5}$ & 0.007819 & 0.153072 & $\mathrm{e}_{10}$ & -31.153714 & -76.072929 \\
\hline
\end{tabular}

\section{Conclusions}

The observation was made in the present work that mass distribution descriptors perform better for cases of interaction of substance with the solid or fixed molecular framework and perform slightly worse for cases of interaction of molecules with liquids, although the level of deviations is coincident with the models utilizing the quantum-chemical descriptors. This can be explained by the nature of descriptors utilized. Although they do describe the charge distribution, the level of information is not sufficient to describe the whole range of orientations available in liquid phase, but for the cases of interaction with solid phase, i.e. the surface, such information is sufficient as only a limited number of orientations is responsible for the contribution to the total adsorption characterizing macroscopic property, and locality of interaction centers does not introduce strict conditions upon the accuracy of the model of interaction. A distinctive characteristics of mass distribution descriptors is that only a limited knowledge about the system is utilized, namely, the chemical formula. No use of quantum-chemical computations is made and no effort is spent for computing or measuring the quantum-chemical parameters of molecules, which makes this method computationally favourable for certain types of research problems. The results of computations show that the introduction of the interatomic valence bound states-specific information may introduce the major changes in the results of modelling making the predictions even more accurate compared to the quantum-chemical or physical-chemical descriptors in the description of physical-chemical objects exhibiting the complex formation properties. The general conclusion attained in present work is that the mass distribution descriptors can at least form a reliable foundation for complementing them by quantumchemical or physical-chemical descriptors in modelling the macroscopic properties of substances.

\section{Acknowledgements}

Akyl Tulegenov acknowledges the lecturership scholarship of the al-Farabi Kazakh National University. Bagdaulet Kenzhaliev acknowledges the funding of the project (KBTU contract 88 ): "Development of basic prerequisites of development of hydrometallurgical processes of extraction of non-ferrous metals from metal-containing sources with the objective of creation of the foundations of innovative technologies."

References (GOST)

Тагер А.А. Физико-химия полимеров. - Москва: Химия, 1968. - 536 с. 
2 Tulegenov A.S., Abramova G.V., Avchukir Kh., Nauryzbaev M.K., Imanbekov K.I. Correlation models in the studies of structure and properties of amides // Chemical Bulletin of Kazakh National University. - 2012. - Is.2. - P.164-170.

3 Baskin I.I., Palyulin V.A., Zefirov N.S. Prediction of the enthalpies of formation of aliphatic polynitrocompounds // Moscow University Chemistry Bulletin - 2001. - Vol.42, Is.6. - P.387.

4 Tulegenov A.S., Kenzhaliev B.K., Berkinbayeva A.N., Khusainov I.I. Prediction of thermodynamic stability constants of transition metalcomplex-es // Chemical Bulletin of Kazakh National University. - 2015. - Is.2. - P.54-60

5 Katritzky A.R., Tamm K., Kuanar M., Fara D.C. Aqueous biphasic systems. Partitioning of organic molecules: a QSPR treatment // Journal of Chemical Information and Modeling. - 2004. - Vol.44, Is.1. - P.136-142.

6 Pankow J. Gas phase retention volume behaviour of organic compounds on Carbotrap graphitized carbon // Journal of Chromatography. - 1991. - Vol.547. - P.488-493.

\section{References}

1 Tager AA (1968) Physical chemistry of polymers. Khimiya, Moscow, USSR. (In Russian)

2 Tulegenov AS, Abramova GV, Avchukir Kh, Nauryzbaev MK, Imanbekov KI (2012) Chem Bull Kazakh Univ 2:164-170. https://doi. org/10.15328/chemb_2012_2164-170

3 Baskin II, Palyulin VA, Zefirov NS (2001) Moscow University Chemistry Bulletin 42:387.

4 Tulegenov AS, Kenzhaliev BK, Berkinbayeva AN, Khusainov II (2015) Chem Bull Kazakh Univ 2:54-60. https://doi.org/10.15328/ $c b 638$

$5 \quad$ Katritzky AR, Tamm K, Kuanar M, Fara DC (2004) J Chem Inf Model 44:136-142. https://doi.org/10.1002/chin.200417223

6 Pankow J (1991) J Chromatogr 547:488-493. https://doi.org/10.1016/S0021-9673(01)88678-7 